\title{
EMPIRICAL ANALYSIS ON THE UTILITY OF RESEARCH DESIGNS IN CHANGE MANAGEMENT
}

\section{ONYANGO JOSEPH ODHIAMBO}

\author{
Senior Lecturer, Strathmore University Business School Nairobi, Kenya
}

Change Management is one discipline that is becoming a subject of interest to many academicians, organizations, consultants and other professionals from various disciplines, industries and sectors. This interest has been on the rise and has heightened research studies building on the existing body of knowledge. In the recent past, there has been an increase in the number of studies being conducted worldwide on Change Management. This paper has focused on the types of research designs being utilized to conduct studies on Change Management. An empirical analysis on the utility of research designs around the discipline of Change Management has been done on randomly-sampled studies, published in peer-reviewed journals, in the last five years. The scope of this study included 100 studies. The reference lists in these studies identified as the sample population, has resulted into a credible source of reference for some of the studies on Change Management undertaken between 2011and 2016. This brings together consolidation of research work from different sources in one paper, and can be adopted as a quick reference for empirical review. Findings of this study has revealed that majority of Change Management research utilizes qualitative research designs (17\%) and case studies (13\%). The study identified 11 types of research designs that included: qualitative, case study, hypothesis testing, empirical reviews, longitudinal, multiple design, exploratory, conceptual, survey, descriptive and experimental research designs. This paper has also provided a high-level description of these research designs and their applicability. From the findings, the utilization of the research designs has been explored around: themes of studies for instance leadership, resistance to change, application of models among others; places where the studies were conducted such as industry or sector, geographical location or across various organizations and the targeted population.
\end{abstract}

KEYWORDS: Change Management, Utility, Research Design \& Methodology

Received: Apr 29, 2017; Accepted: May 26, 2017; Published: Jun 07, 2017; Paper Id.: IJBMRJUN20175

\section{INTRODUCTION AND BACKGROUND}

The design of the research process is always regarded as the major formidable aspect of any research, to ensure integration and facilitation of smooth sailing of the various research operations, thereby, making the research as efficient as possible (Kothari, 2009). However, the need of well-thought research designs as a methodological component of the study is at times never realized, especially for fast growing disciplines. Change Management as a discipline in the recent past has demonstrated a lot of interest not only for organizations, change management professionals, change management consultants, but also academicians as a subject of research and teaching in the institutions of learning. The subject of Change Management cuts across all sectors and industries. This has been necessitated by the fact that several organizations find themselves in a constant state of transformation. According to Kurb (2002), organization transformations takes many forms and have many banners around revitalization, re-engineering, restructuring, mergers and acquisitions, joint ventures, entry into new markets among others. Against this background, several studies have been carried out and some have formed part 
of case file for Change Management as well as reference in academic sphere in the body of knowledge.

There are several research designs that have been developed, used and tested over the years. In the past decades, the field of research has witnessed multiplication of approaches to investigatory or inquiries making choices on their designs. A general framework of research design can be adopted to provide guidance about all facets of the study. This ranges from assessing the general philosophical ideas being the inquiry to the detailed data collection, analysis procedures and presentation of the findings.

A research design can be thought of as a structure of research or the "glue" that that holds all the elements of the research. It is therefore important to the relationship among the various designs that would assist the researcher in making the choice of a design, and thinking about the strengths and weakness of different research design as appropriate to the study (Kombo \& Tromp, 2006). This study has identified and discussed many of research designs and depicted some of the studies in Change Management that have adopted such research designs. Consequently, the major objective of this study was to establish the dominant research design and methodologies used in Change Management studies. The primary research question for this study was: How have the various research designs been utilized in change management studies?

The question of utility of research design cannot be discussed without highlighting qualities of effective research designs. Some of these include such aspects like systematic and logical, by addressing the questions raised in the study, contributing to accurate and fair interpretation of the results, clarify to the researcher the study population and how the study will be conducted and finally contribute to deeper insights and better understanding of the research topic. Appropriate research design for a research problem is one, that makes consideration to the following factors: The means of obtaining information, the availability and the skills of the researcher and his/her staff if any, the objective of the problem to be studied, the nature of the problem to be studied and the availability of time and money for the research work (Kothari, 2009). The reference lists in these studies as identified from the sample population have resulted into a credible source for reference for some of the studies on Change Management undertaken between 2011and 2016. This study thus brings together consolidation of research work from different sources in one document and a contribution to the body of knowledge.

\section{METHODOLOGY}

The scope of the study involved review of Change Management researches published in peer-reviewed journals between 2011 and 2016. A sample of 100 studies were identified randomly and reviewed to constitute the main data of studies. Analysis and inferences were made based on the findings. The empirical studies reviewed form part of the reference to this study and can be adopted as the appendix outlining some of the interesting studies conducted in Change Management in the recent past.

Literature from various research methodology books was also reviewed on the key elements of each of the research designs. This created a pivotal position as a case for each of the designs. The research entailed high level review and documentation of the key tenets of research designs such as qualitative case studies, hypothesis testing, empirical reviews, longitudinal, multiple design, exploratory, conceptual, survey, descriptive and experimental research designs.

\section{FINDINGS AND DISCUSSIONS}

Analysis of the 100 studies on Change Management used in this study indicated that most of the studies utilized qualitative research design techniques $(17 \%)$. This was closely followed by case studies $(13 \%)$. The third in the order of 
utility was hypothesis testing (11\%). Additionally, empirical study design, longitudinal study design and multi designs were equally distributed at $10 \%$ each. Descriptive design, experimental designs, and surveys constituted less than $10 \%$ in each of the category of the total in their respective design type. The above narrative is illustrated in table 1 below.

Table 1: Summary of the Findings

\begin{tabular}{|c|c|}
\hline Research Design & Percentage $(\%)$ \\
\hline Qualitative & 17 \\
\hline Case Study & 13 \\
\hline Hypothesis Testing & 11 \\
\hline Empirical Reviews & 10 \\
\hline Longitudinal & 10 \\
\hline Multiple Design & 10 \\
\hline Exploratory & 9 \\
\hline Conceptual & 7 \\
\hline Survey & 7 \\
\hline Descriptive & 4 \\
\hline Experimental & 2 \\
\hline Total & 100 \\
\hline
\end{tabular}

\section{Qualitative}

Qualitative studies predominantly trace their roots to science traditions in anthropology and sociology. Isadore \& Benz(1998) provided an over arching description of qualitative research design as those that are generally subsumed under the heading ethnography. They further broke this down to include such headings and names like case studies, field studies, grounded theory, document studies, naturalistic inquiry, observational studies, interview studies, and descriptive studies. Based on this understanding, the philosophy in this perspective emphasizes the phenomenological basis of a study as a way of elaborating in detail the meaning of the phenomena for the people or culture under examination. Key to this description is the aspect of culture that is a central theme in Change Management. Overall, Qualitative research design has a long and vibrant history in the social sciences, health sciences, and humanities and has been applied seamlessly across various studies (Given, 2008).

Most studies in Change Management identified utilized qualitative design as represented with 17 per cent of the sampled population. This study has classified the utilization of the qualitative design into three major categories. The first category is of the case, where qualitative design was used in a survey kind of research that involved many organizations. For instance, Kafel \& Casadesus (2016) analyzed how the order of management system standards (MSSs) implementation in an organization and its level of integration are changed during the time of the standard implementation in 866 organizations. Conversely, Yazici, Köseoglu, \& Okumus (2016) investigated change factors that drive growth for independent 92 hotel firms on island of Cyprus. Initially, six years back, McCabe (2010) had used the same approach to enhance understanding of organizational change by countering managerial and critical assumptions that it is possible to break with the past. Reissner (2010) also used a similar approach to investigate how organizational change can affect the development of personal identities using qualitaitve approach. Three manufacturing firms, one each from the UK, South Africa and Russia, were studied to investigate sensemaking under conditions of change.

The second categorization of qualitative research design was based on tools used to collect data as pridominatly specified in the major terms of description of the research design utilised. These included interviews and questionnaires. Sghari(2016) used a questionnaire to collect data to analyse proposed change induced by the implementation of a Global 
Banking System. Similarly, Johnson (2016) used a questionnairetoidentify three major dimensions to change excessiveness: change frequency, extent, and impact. James \& Frank(2015) used a questionnaire to assess Culture Change Managementthat strengthens the total organization's capability and willingness to accept and prosper in a rapidly changing worldwide environment. On a similar account, Canet-Giner, Fernández-Guerrer, \& Peris-Ortiz(2010), used a semi-structured questionnaire to gather information along with documents and additional information thereafter, thus facilitating the triangulation process.

Using interviews as the main data collection techniques:Franklin (2014) used interviews to collect data to demonstrate defining howchange is to be planned and implemented is as important for its success as defining what the change is expected to achieve. To achive this, all information was drawn from questions asked to senior managers on the challenges raised from the transformation of their organizations. Nyström, Höög, Garvare, Weinehall, \& Ivarsson (2013) used imterviews to investigate the change strategies used over time and describe the potential variation in key change agent views, using a framework inspired by De Caluwé and Vermaak's multi paradigm change typology. As an aspect of interview, Mertkan, Gilanlioglu, \& McGrath(2016) employed qualitative approach that involved in-depth interviews with key institutional managers to explore the complexity of developing into an international institution from the perspective of higher education leaders. Recently, a similar approach has been used in the banking sector bySridarran \& Fernando (2016) to investigate why change is not managed during outsourcing of financial management services and how it can be managed.

The other categorywas identified as associated with the various models used in Change Management. Some of the typical studies in this category that utilised qualitative approach included such studies like, Fink \& Dauber (2016) that sought to establish that Slawek Magala's theory of management of meaning in organizations can be considered as a step towards a generic theory of organisational change. Close to this was Karimidorabati, Haas, \& Gray(2016) study that evaluated and quantified the difference between levels of automation of change management processes and to provide input for determining the use of automation systems for Change Management. Also identifed is a study to provide a framework that explains how individual organizational members' self-construction processes motivate them to support or reject decoupling as a form of resistance to institutionally mandated change by Pitsakis, Biniari, \& Ku(2012). Finally, in this type of design on a similar account, Bhatnagar, Budhwar, \& Srivasta, (2010) to examine developments in the field of organizational change with reference to the context of India.

\section{Case Study}

Dul \& Hak (2008) provided a simplistic definition of case study in contrast to survey by stating that its methodological characteristic is a distinction from other research strategies such as the survey. Consiquently, a case study basically is an inquiry of only one single instance (the case of entity), or sometimes a small number of instances, of the object of study. In details two main types of case study have been identifed as the single case study in which data from one instance is enough to achieve the research objective, and the comparative case study where the data required is from two or more instances to achieve the research objective of the study. From the study, findings analysis 13 per centof the sampled studied were based on case studies.

The review has demonstrated varied application on the utilization of case study approach. For instance, one of the studies applied case study design for conceptual development of illustrations.(Rill, 2016). Closely associated to this is a study conducted on the Impact of change readiness on commitment to technological change, focal, and discretionary 
behaviors: Evidence from the manufacturing sector of Karachi (Muhammad, 2016). In this study, confirmatory factor analysis was used to evaluate the reliability and validity of the measurement model technological change. In the same category is a case study on evidence and leading indicators of change success (Arnold, 2015). Brown (2012) conducted a case study using a variation of the Washington University Sentence Completion Test to document how leaders with a highly-developed meaning-making system design engage in sustainability initiatives. Another case study in a related subject around sustainability of change by Millar, Hind, \& Magala (2012) was conducted, whose aim was to introduce the special issue on the theme of sustainability and the need for change.

Design of case study deployed on a particular perspective was also found out to be a specific method. For instance, a study conducted by Parker, (Parker, Charlton, Ribiero\& Raghuvar(2013) used a case study approach to critically argue the value of project-based management in the change management process with focus on PRINCE2 and PMBoK. Aspects of case study such as inductive has been utilized by Xiaojun(2016) to explore how institutional environments interact with organizational change in a novel context as a case of Chinese state-owned enterprise. In a very special case, qualitative cases study was conducted by Hansen, Randolph, Robinson, Alejandra \& Lee (2015) to track an entrepreneur's efforts to create a new financial instrument and get it accepted and traded on the New York Stock Exchange.

The approach of case study coupled with other research designs was also identified. For instance, in studies conducted by Lee, Ridzi, Lo, \& Coskun (2011) employed a questionnaire survey, non-participant observation and semi-structured interviews as part of a larger study of healthcare change management. Alternatively, Jay (2014) followed a case study design applying integration method for the study of changes over time. Two sets of in-depth semi-structured interviews underwent content analysis to derive thematic findings. Case detail was also provided to frame the results.

\section{Hypothesis Testing}

Hypothesis testing type of research design is normally identified with the formulation of hypothesis and testing the analysis of the relationship between non-manipulated variables. As such, hypotheses are empirically testable statements about relationships between concepts in a study that are normally operational zed through variable(Miller \& Whicker, 1999). Hypothesis can further be classified as causal or co relational, directional and non-directional. However, capacity to test causal hypotheses and prove causation must be built into the research design. In this study, 10 per cent of the identified studies utilized hypothesis testing research design.

One of the emerging trends found in this study is application of the design in various parts of the world around different studies on Change Management. For instance, Yeo \& Marquardt (2015) study in East Malaysia focused on influence of technology on organizational change during an electronic government implementation in a public organization while Simpson (2012) study was on complexity and change management in Englands Churches. Haffar, Al-Karaghouli \& Ghonei (2014) researched on the influence of organizational culture on individual readiness for change (IRFC) in Syrian manufacturing organizations. In this study a total of four hypotheses were proposed for testing in order to measure the level of IRFC and to identify the cultural profiles and characteristics of these organizations. Another study using the same approach of hypothesis testing was conducted in Spain by (Llamas-Sanchez, Garcia-Morales, \& Martin-Tapia, 2013). It examined how Spanish local councils responds to changes in their institutional context by implementing a sustainable practice. 
Identified studies were around hypothesis testing for purposes of building theoretical models. Wu, Wei \& Liang (2011), used archival data from annual reports to form the sample and used hypothesized model relationships to test hypothesis through regression analysis. The study was aimed at building of a theoretical model to explore how team pay disparity and resource slack moderate the effects of top management team diversity on strategic change. Lee, Park \& Kim (2014) used negative binomial regression to test the hypotheses, based on knowledge creation of 410 mobile researchand development workers in 75 high-technology Margers and Acquisitions. This was to examine the relationship between change in organizational identity and knowledge creation of mobile research and development workers.

The other category in hypothesis testing was on the theme of leadership and management. In this case, Mingze, Liu, Han\& Zhang(2016) used data from 203 employees and 80 supervisors in one information technology company to examined the mediating role of thriving at work and the moderating role of autonomy between empowering leadership and change-oriented. Alternatively, Sjoerd, Schalk\& Fre (2016) tested hypothesis to develop a model on how business manager's perception on employee's psychological contract influences his or her attitude toward an organizational change. As well, Dominguez, Galán-González \& Barroso (2015) tested hypothesis to know how strategic change processes unfold over time and their potential consequences for firms.

\section{Empirical Reviews}

According to Miller \& Whicker (1999), empirical research draws its data result from observations of real world phenomena. Data measurements of empirical studies represent the operationalization of a concept across different subjects or cases. Fundamentally, empirical studies from a positivist perspective are normally associated with natural science researches. In social science, empirical reviews have always been associated with review of other studies previously done on the related subjects. Consequently, Greener (2008) asserted that it promotes the idea of experimentation and testing to prove or disapprove hypothesis through a deductive process then generate new theories by putting facts together to generate the new principles through the inductive process. The main approach in this design as adopted in social and business studies has been through synthesis of particular topics and summaries across studies. Of the studies identified, 10 per cent were based on empirical review. The studies identified were further clustered as follows: Three of the studies focused on review of literatures around public sector research. This included studies done by Brown, Rose, \& Gordon, 2016; Xerri, Nelson, \& Brune, 2015; Manning, 2012; and Sushil, 2010. The other set of papers were based on lierature review. This inlcuded such studies around changes that occur in the organization during its transition to a new version of the ISO 9001:2015(Kristina, Kisela, \& Sutoova, 2016). Alternatively, a critical analysis as part of empericl review was conducted byNoora (2013) on taken-for-granted assumptions revealed by a literature utilizing practice theory approach in which human behavior and social context are intertwined. The analysis of this theoretical paper focused on practices, praxis and practitioners in organizational change. Three of the studies in this category focused on general literature review as a critical analysis on the exisisting literature. The topic under this category are considered from both a contemporary and an evolutionary perspective (Erakovich \& Trisha, 2013; Soriano, 2012). Finally, Pardo-del-Val \& Sal ( 2012) approach was from a review of previous literature as an empirical research but preceeded to test the existence and signs of relationships between participation and organizational change. The authors used scales and other measures already published to perform correlation analysis on relationships among variables. 


\section{Longitudinal}

Longitudinal research designs are commonly adopted for studies that are conducted over a long period. The recent development in this research design in business and social science indicates that too little longitudinal research have been conducted and that even when longitudinal data was collected in a number of studies was often analyzed crosssectional(Liberman, 2008). To support the relevance of longitudinal design against Liberman, (2008) assertions, Magnusson \& Casaer (1993) contended that longitudinal research is essential element in the investigation of human development over time, with considerable advantages over the more widely used cross-sectional research designs. These tie well with the subject of Change Management that is at the core of human development.

Many of the studies in Change Management adopt longitudinal design. In this study, 10 per cent of the sampled population utilized longitudinal approach. The studies identified were classified around some identical emerging themes. First of these were longitudinal studies anchored on other research designs. For instance, Imran, Rehman, Aslam \& Bilal (2016) used multiple case studies approach as part of the longitudinal design. A multiple case study over a period enables the comparison of pre- and post-analysis of the changes. Similarly, Cuevas-Rodriguez, Guerroro-Villegas \& Valle-Cabrera (2016) adopted temporal research design to get the appropriate responses from the targeted population in two stages such as pre-change (Time-1) and post-change (Time-2). Alblas \& Wortmann (2012) used longitudinal case study at a leading microlithography manufacturing company. The study allowed the disclosure of the complexities of engineering Change Management and provided guidelines for handling the resulting problems arising from managing these various types of change.

The other aspect is relatedto the duration of the study. One of the studies identified was conducted over a period of 38 years (Vora, 2013). The purpose of this study was to make a case for achieving business excellence through sustainable change management. Bordum (2010), also conducted a study using longitutional on development of strategic management and contains a rational reconstruction of core assumptions relevant to managing change. Similarly, Zuber-Skerritt \& Louw(2014) for a period of two years embarked on evaluating leadership development program senior academic staff to establish the success, limitations and overall impact of the program. Finally, Kilkelly (2014) conducted a study to explain why change programs fail in spite of best practice processes and procedures and to examine the improvements that can be made by developing effective change leaders over a period of three years.

\section{Multiple Designs}

Multiple research designs are always a culmination of use of more than one research design in a study to enhance its effectiveness. According to Sage Dictionary of Social Research Methods, multiple research design is associated with the concept of applied research, evaluation research, good practice studies, and methodological pluralism. As such mixedmethods that imply adoption of multiple research designs are mostly applicable to policy-related research for purposes of enhancing validity (Jupp, 2001). Based on the findings of this study, 10 per cent of the identified studies used multiple research designs.

Among the studies identified, Matos, Simoes, \& Esposito(2014) conducted a study on how communication nature influences change process. Mixed methodology was applied that included case study, qualitative and quantitative techniques to analyze and characterize resistance to change and communication nature within one organization under a radical change process. On a similar account around the theme of resistance to change management, Huang (2015) used 
multiple research designs to establish how to overcome invisible obstacles in organizational learning with a moderating effect of employee resistance to change. This study leveraged on partial least squares analysis to examine the data. Chen, Werle \& Moser (2016) also conducted a study comparing the critical success factors between two groups of European mergers and acquisitions in China and Chinese with those in Europe. Mergers and Acquisitions are also characterised with resistance to change.

From a sector wide perspective, multiple research design was seen to be used in health sector organization Change Management studies. In this case two studies were from health sector. These were studies conducted by Kelliher $\&$ Parry(2015) on change in healthcare: The impact on National Health Service managers. Maheshwari \& Vohra( 2015) used the same approach to provide a conceptual framework that identifies critical practices that support organizational change and examines their impact on employee perception and commitment to change. On the other hand the same design has been utilized in the education sector as identified in two studies. Sorensen \& Sarjeant-Jenkins (2016) used multiparty approach to explore how to address the resulting challenge the University of Saskatchewan associated with the change. Wilhoit, et al.(2016) assessed the use of an affordance approach to understand how university faculty use and value their workspace and respond to proposed spatial changes.

\section{Exploratory}

According to Kothari(2009), exploratory research studies are also termed as formulate research studies. The main purpose of exploratory studies is to formulate a problem for more precise investigation or of developing the working hypotheses from an operational point of view. The major emphasis in this kind of research design is on the discovery of new ideas and insights. As such the exploratory research design is appropriate for studies that must be flexible enough to provide opportunity for considering different aspects of a problem under study. However, Jupp (2001) asserts that exploratory research subsequently acts as guide to further inquiry. This implies that by its nature, exploratory research design's shape and content can be based on theorizing previous research findings for purposes of further in-depth enquiry on the research problem.

In terms of utility from a sector perspective, Audet \& Mario (2016) conducted a research using explorarory research design in a health sector organization. The study in its operationalization adopted various techniques for systematic collection of data that included: field notes, 746 hours of observations, proceedings, 186 interviews, journals, focus groups and discussion forums. On a similar account, Dasborough, Lamb \& Suseno (2015) conducted an exploratory research in the education sector with a focus on understanding emotions in higher education change management.

Exploratory research design has also been used to explore application of aspects of leadership and management skills, within organization as well as dimension of communications. These included such studies like:Luo, Lynda \& Diether (2016) that focused on how leader communication styles promote employees' commitment at times of change. Around the same theme, Lewis, Romanaggi, \& Chapple (2010) research was on a broad perspective of leadership aspect that explored six key imperatives that enable executives to overcome resistance to change such as:sustain workforce performance through difficult challenges, provide effective leadership and support the new workforce behaviors.

The other category of exploratory designs was depicted around business processes and business reingineering activities. Theseincluded those studies like:Bansal (2015) study on post-integration mechanisms carried out by five multinational mergers and acquisitions (M \& A) transactions that took place in Indian context;Sikdar \& Payyazhi(2014) on 
process model of managing organizational change during business process redesign. This paper provided the best fit description of exploratory research design as provided byKothari (2009). In this sense, the purpose of the study was to provide a framework for managing organizational change in a structured manner during workflow redesign, that was considered a perspective missing in the literature on business process management (BPM) implementation. Rusly, James \& Sun (2012) also conducted an exploratory research on resistance to technological changes among communities of practise in organizations. Closely related to the theme of technology adaptation and change is the study conducted by Armengot, Carbonell, \& Parellada (2010) that analyzed the ethnic profile of the entrepreneurs in relation to business activity, the reasons for creating the firm and the creation processregardless of place of birth or nationality.

\section{Conceptual}

Kothari (2009) described conceptual research as that which is related to some abstract ideas or theory as generally used by philosphers or thinkers to generate new concepts to reinterpret existing ones. While theoritical method presumes an out-there reality that provides input to cognitive operations, discursive conceptual design as an approach focuses on the way both 'reality' and 'mind' are constructed by people conceptually, in language and in the course of their execution of various practical tasks. In this case is the appication of Change Management models and theories in execution of a change process (Jupp, 2001).

This study identified six studies making7 percent of the total sample population that are associated with conceptual research design as utilized in change management studies. Some of these studies included: organizational diagnosis, organizational duress, Parrhesia by Sementelli(2016) where Foucauldian concept is introduced into the theory and practice of organization development and change management. In its perspective, the study challenges Habermasian a priori assumptions about organizational diagnosis and intervention. In the same period, Brandon \& Linski (2016) developed a conceptual paper using contemporary literature on resistance to organizational change to make the case that the existing paradigm is one of negativity and deficiency. Close to this is also the application of conceptual design to integrate complexity theories to understand and cope with large system initiatives from the perspective of change agents in organizations.

Findings also depicted conceptual designs with case illustrations. Typical examples include studies that focused on conceptualization of resonant co-creation as a framework for cultivating strategic innovation and organizational change. Another study in this area was on "Modeling the cultural dynamics of resistance and facilitation: Interaction effects in the OC3 model of organizational change" by Latta, (2015). In this study, the conceptual model is introduced on the conceptual definition of facilitation parallels of the psychosocial construction of resistance. The conceptualization in this sense is used to depart from traditional views that casted these constructs as opposites within the context of the OC3 Model.

\section{Surveys}

Surveys usually involve a large number of respondents and are always described as opposed to case studies. One of the key characteristics of survey research design is that it always covers a diverse spectrum of statistical concepts and procedures used to help in analyzing and interpreting the data that surveys generate. This normally includes such concepts like: balanced repeated replication, control group, design-based estimation, hot-deck imputation, margin of error, outliers, perturbation methods, random assignment and sampling among others (Lavrakas, 2008).

Based on the findings in this study, 7 per cent of the identified studies adopted survey research design. The first of 
categorization of surveys based on the findings of this study were surveys conducted across several organizations. These include such studies as of multi-level approach of Feng, Huang\& Zhang (2016) that collected data from full-time employees working in 43 companies located in five major cities in China including Beijing, Yantai, Chengdu, Xi'an, and Chengde. Ultimately, a total of 192 managers and 756 direct subordinates from 112 groups completed the survey. Similarly, Tummers, Kruyen, Vijverberg \& Voesenek ( 2015) collected data from three large public healthcare organizations in the Netherlands to investigate the effects of five important human resource change management practices on proactivity and vitality. Closely related but from an industry perspective, Ahmed, Balzarova, \& Cohen (2015) used survey design to examine the context of change process in the electricity industry in New Zealand. Batra (2016) collected data on a survey design from 103 Indian new venturesto argue and empirically prove that firms in emerging economies need to persist with their strategies during their formative years in order to acquire sustainable competitive advantage.

The other categorization identified was surveys within an organization that involves several subjects. Koller (2016) used survey design to examine the concept of adaptive advantage and to seek to improve its understanding and application for the development of a new perspective on adaptive strategy design. This was done through drawing out the individual contributions in a survey. Helpap \& Bekmeier-Feuerhahn (2016) surveyed 261 employees with a vignette study and performed structural equation modeling on the results to test the model of infusion on employee sense making. Caliskan \& Isik (2016) also used a survey design to investigate employee readiness for their organization's global change and the predictive effect of their personality and perception of change in a retail company.

\section{Descriptive}

Kerlinger (1973) decribed the major purpose of descriptive research design as the description of the state of affairs as it exists. As such, descriptive studies are not only restricted to fact finding but may often result into formation of important principles of knowledge and solutions significant to the problem. Descriptive research often involves broad objectives rather than tests of specific hypotheses. For example, it might have a goal to describe and analyze how people behave in a changing environment or how people adopt to specific models of change.

In this study 4 per centof the reseaches identifed with descriptive research design. One of the studies is by Lowe, Rod, Kainzbauer, \& Ki-Soon (2016), which explored how different relationships are characterized between actors in interaction and determine whether social theories of practice resonate as being practical to managers. A similar study of the same nature done by Descubes \& McNamara(2015) in the public sector space was on learning from experiences to address the gaps and silos between top-level macro-strategy planning and operational micro-management on-going challenges in a contemporary New Public Management (NPM) major organizational change context. On the same breadthRodwell, Flower, \& Demir, (2015) set to investigate whether occupational social contexts differentiate the processing of changes in the employment relationship, as represented by the psychological contract.

\section{Experimental}

Experiment research design is characterized by much greater control over the research environment and in this case, some variables are manipulated to observe their effect on other variables. It is rather imperative to distinguish experimental design from simulation. Simulation approach involves the construction of an artificial environment within which relevant information and data can be generated (Kothari, 2009). It has been observed that experimental design studies are predominantly used in psychological studies (Davis, 2003). Change Management as a discipline heavily relates 
to Psychology, as it is more associated with how people behave in a changing context.

It is however, noted that very minimal studies in Change Management as depicted from the sample population utilized experimental design. This is supported by the fact that only 2 per cent of the studies utilized this kind of research design. One of the studies identified was by Ainsworth \& Feyerherm (2016). This experimental study was a comprehensive model for diagnosing Trans-organizational Systems (TSs). In constructing the model existing literature is integrated with the enduring organization development. The authors developed a comprehensive model to diagnose organizations at three levels: individual, group, and organization thereby proposing additional fourth after validating the experiment's conclusion into a new higher order level of the $4^{\text {th }}$ TS level. Crestani ( 2016) conducted an experimental research design study using Kemmis and McTaggart framework for studyingthe practices based on individual-social, objective-subjective dichotomies leading to an integrated reflexive-dialectical approach(Pardo-del-Val \& Sal, 2012).

\section{CONCLUSIONS AND IMPLICATIONS}

This paper at a high level appreciated the fact that Change Management as a discipline continues to attract attention on research around it, and has continued to demonstrate a lot of interest not only for organizations, Change Management professionals and consultants, but also for academicians as a subject of research and teaching. This shows there is need to consolidate aspects of the studies undertaken on the discipline so far. This paper in its quest to explore the utility of research designs on Change Management is a double fold as it brings together the body of knowledge in research methods and Change Management. From the analysis of the findings the question of effectiveness and efficiency of the research designs as applied is of interest. It is also imperative to take note of the limitation of this study, as it has not provided a survey of all the studies conducted around Change Management. However, the random sample of 100 studies provides a preliminary platform to make inference about how research designs have been utilized in the last five years. Consequently, it is of benefit to students intending to undertake studies in Change Management, other scholars interested in Change Management, consultants and professionals of Change Management and organizations undertaking studies to review implementation of change management initiatives. Finally, the study has also provided the link between aspects of Change Management and associated researches on the same subject in relation to research methodology. Of importance in the purpose of this research is how studies are underpinned by the kind of research designs used. The list of references used in this study, as provided, also constitutes an integral part of the body of the study, as a key reference to some of the studies already undertaken in the field of study in Change Management.

\section{REFERENCES}

1. Ahmed, H., Balzarova, M., \& Cohen, D. A. (2015). Evolutionary change stimuli and moderators - evidence from New Zealand. Journal of Organizational Change Management, 28(4), 546 - 564.

2. Ainsworth, D., \& Feyerherm, A. E. (2016). Higher order change: a transorganizational system diagnostic model. Journal of Organizational Change Management, 29(5), 769 - 781.

3. Alblas, A. A., \& Wortmann, J. C. (2012). Managing large engineering changes: The case of a high-tech microlithography equipment manufacturer. International Journal of Operations \& Production Management, 32(11), 1252 - 1280.

4. Armengot, C. R., Carbonell, J. R., \& Parellada, F. S. (2010). The immigrant entrepreneur in the international change: A managerial analysis according to demographic profile. Journal of Organizational Change Management, 23 (4), 377 - 395.

5. Arnold, P. (2015). Evidence and leading indicators of change success. Strategic Directon, 31(10), 1-5. 
6. Audet, M., \& Mario, R. (2016). Using strategic communities to foster inter-organizational collaboration. Journal of Organizational Change Management, 29(6), 878 - 888.

7. Bansal, A. (2015). Understanding the integration mechanisms practiced during organizational change: Evidence from five $M$ \& A transactions. Journal of Organizational Change Management, 28(6), 929 - 947.

8. Batra, S. (2016). Do new ventures benefit from strategic change or persistence? A behavioral perspective. Journal of Organizational Change Management, 29(2), 310 - 319.

9. Bhatnagar, J., Budhwar, P., \& Srivasta, P. (2010). Organizational change and development in India: A case of strategic organizational change and transformation. Journal of Organizational Change Management, 23(5), 485 - 499.

10. Bordum, A. (2010). The strategic balance in a change management perspective. Society and Business Review, 5(3), $245-258$.

11. Brandon, M., \& Linski, C. M. (2016). Shifting The Paradigm: Reevaluating Resistance to Organizational Change. Journal of Organizational Change Management, 29(6), 963 - 972.

12. Brown, B. C. (2012). Leading complex change with post-conventional consciousness. Journal of Organizational Change Management, 25(4), 560-575.

13. Brown, D. R., Rose, D., \& Gordon, R. (2016). De-commoditizing change management: A call for the re-positioning of change management on IT projects. Journal of Organizational Change Management, 29(5), 793 - 803.

14. Caliskan, S., \& Isik, I. (2016). Are you ready for the global change? Multicultural personality and readiness for organizational change. Journal of Organizational Change Management, 29(3), 404 - 423.

15. Canet-Giner, M. T., Fernández-Guerrer, R., \& Peris-Ortiz, M. (2010). Changing the strategy formation process in a service cooperative. Journal of Organizational Change Management, 23(4), 435 - 452.

16. Chen, Y., Werle, H., \& Moser, R. (2016). Comparing critical success factors between European M\&As in China and Chinese M\&As in Europe: A mixed-method analysis. Journal of Organizational Change Management, 29(7), 1217 - 1236.

17. Crestani, I. (2016). Change Communication: Emerging Perspectives for Organisations and Practitioners,. Emerald Insight, $225-244$.

18. Cuevas-Rodriguez, G., Guerroro-Villegas, J., \& Valle-Cabrera, R. (2016). Corporate governance changes, firm strategy and compensation mechanisms in a privatization context. Journal of Organizational Change Management, 29(2), 199 - 221.

19. Dasborough, M., Lamb, P., \& Suseno, Y. (2015). Understanding emotions in higher education change management. Journal of Organizational Change Management, 28(4), 579 - 590.

20. Davis, S. F. (2003). Handbook of Research Methods in in Experimental Psychology. Oxford: Blackwell Publishing Ltd.

21. Descubes, I., \& McNamara, T. (2015). Theatre-based learning to foster corporate legacy change. Journal of Organizational Change Management, 28(4), 565 - 578.

22. Dominguez, M. C., Galán-González, J. L., \& Barroso, C. (2015). Patterns of strategic change. Journal of Organizational Change Management, 28(3), 411 - 431.

23. Dul, J., \& Hak, T. (2008). Case Study Methodology in Business Research. Burlington: Elsevier Ltd.

24. Erakovich, R., \& Trisha, A. (2013). Cross-sector collaboration: management decision and change model. International Journal of Public Sector Management, 26(2), 163 - 173.

25. Feng, C., Huang, X., \& Zhang, L. (2016). A multilevel study of transformational leadership, dual organizational change and innovative behavior in groups. Journal of Organizational Change Management, 29(6), 855 - 877. 
26. Fink, G., \& Dauber, D. (2016). Slawek Magala's view on management of meaning and organisational change: An essay in honour of Slawek Magala. Journal of Organizational Change Management, 29(1), 59 - 67.

27. Franklin, M. (2014). 3 lessons for successful transformational change. Industrial and Commercial Training, $46(7), 364$ - 370.

28. Given, L. M. (2008). The Sage Encyclopedia of Qualitative Research Methods (Vol. 1\&2). Thousands Oak California : Sage Publication Inc.

29. Greener, S. (2008). Business Research Methods. Chicago: Ventus Publishing ApS.

30. Haffar, M., Al-Karaghouli, W., \& Ghonei, A. (2014). "An empirical investigation of the influence of organizational culture on individual readiness for change in Syrian manufacturing organizations. Journal of Organizational Change Management, 27(1), 5 - 22 .

31. Hansen, H., Randolph, A., Robinson, R. E., Alejandra, M., \& Lee, J. H. (2015). Institutional judo: how entrepreneurs use institutional forces to create change. Journal of Organizational Change Management, 28(6), 1076 - 1093.

32. Helpap, S., \& Bekmeier-Feuerhahn, S. (2016). Employees' emotions in change: advancing the sensemaking approach. Journal of Organizational Change Management, 29(6), 903 - 916.

33. Huang, R.-T. (2015). Overcoming invisible obstacles in organizational learning: The moderating effect of employee resistance to change. Journal of Organizational Change Management, 28(3), 356 - 368.

34. Imran, M. K., Rehman, C. A., Aslam, U., \& Bilal, A. R. (2016). What's organization knowledge management strategy for successful change implementation? Journal of Organizational Change Management, 29(7), 1097 - 1117.

35. Isadore, N., \& Benz, C. R. (1998). Qualitative-quantitative Research Methodology : Exploring the Interactive Continuum. Illinois : Southern Illinois University Press.

36. James, H. H., \& Frank, V. (2015). Cultural Change Management. International Journal of Innovation Science, 7(1), 55 - 74.

37. Jay, J. (2014). Managing Change After the Merger: The Value of Pre-Merger Ingroup Identities. Journal of Organizational Change Management, 27(3), 430 - 448.

38. Johnson, K. J. (2016). The dimensions and effects of excessive change. Journal of Organizational Change Management, 29(3), $445-459$.

39. Jupp, V. (2001). The Sage Dictionary of Social Research Methods. London: Sage Publications Inc.

40. Kafel, P., \& Casadesus, M. (2016). The order and level of management standards implementation: Changes during the time. The TQM Journal, 28(4), 636 - 647.

41. Karimidorabati, S., Haas, C. T., \& Gray, J. (2016). Evaluation of automation levels for construction change management. Engineering, Construction and Architectural Management, 23(5), 554 - 570.

42. Kelliher, C., \& Parry, E. (2015). Change in healthcare: the impact on NHS managers. Journal of Organizational Change Management, 28(4), 591 - 602.

43. Kerlinger, F. N. (1973). Foundations of Behavorial Research. New York: Holt Renehart and Winston.

44. Kilkelly, E. (2014). Creating leaders for successful change management. Strategic HR Review, 13(3), 127 - 129.

45. Koller, M. R. (2016). Exploring adaptability in organizations: Where adaptive advantage comes from and what it is based upon. Journal of Organizational Change Management, 29(6), 837 - 854.

46. Kombo, D. K., \& Tromp, D. L. (2006). Proposal and Thesis Writing: An Introduction. Nairobi: Pauline Publications Africa. 
47. Kothari, C. K. (2009). Research Methodology: Methods and Techniques (Second ed.). New Delhi: New Age International ( P ) Limited.

48. Kristina, Z., Kisela, M., \& Sutoova, A. (2016). Intelligent approaches for an organisation's management system change. The TQM Journal, 28(5), 760 - 773.

49. Kurb, M. (2002). Management Consulting: A Guide To Profession (Fourth ed.). Geneva: International Labour Organisation.

50. Latta, G. F. (2015). Modeling the cultural dynamics of resistance and facilitation: Interaction effects in the OC3 model of organizational change. Journal of Organizational Change Management, 28(6), 1013 - 1037.

51. Lavrakas, P. J. (2008). Encyclopedia of Survey Rsearch Method (Vol. 1\&2). Carlifonia: Sage Publication Inc.

52. Lee, J., Park, N. K., \& Kim, H. (2014). "The effect of change in organizational identity on knowledge creation by mobile R\&D workers in M\&As. Journal of Organizational Change Management, 27(1), 41 - 58.

53. Lee, V., Ridzi, F., Lo, A. W., \& Coskun, E. (2011). A healthcare case study of team learner style and change management. Journal of Organizational Change Management, 24(6), 830-852.

54. Lewis, E., Romanaggi, D., \& Chapple, A. (2010). Successfully managing change during uncertain times. Strategic HR Review, $9(2), 12-18$.

55. Liberman, A. M. (2008). The Long View of Crime: A synthesis of Longitudinal Research. New York: Springer.

56. Llamas-Sanchez, R., Garcia-Morales, V., \& Martin-Tapia, I. (2013). Factors affecting institutional change: a study of the adoption of Local Agenda 21 in Spain. Journal of Organizational Change Management, 26(6), 1045 - 1070.

57. Lowe, S., Rod, M., Kainzbauer, A., \& Ki-Soon, H. (2016). Exploring the perceived value of social practice theories for business-to-business marketing managers. Journal of Organizational Change Management, 29(5), 751-768.

58. Luo, W., Lynda, S. J., \& Diether, G. R. (2016). How does leader communication style promote employees' commitment at times of change. Journal of Organizational Change Management, 29(2), 242 - 262.

59. Magnusson, D., \& Casaer, P. (1993). Longitudinal research on Individual Development: Present and Future Perspectives. Cambridge : Cambridge University Press.

60. Maheshwari, S., \& Vohra, V. (2015). Identifying critical HR practices impacting employee perception and commitment during organizational change. Journal of Organizational Change Management, 28(5), 872 - 894.

61. Manning, T. (2012). Managing change in hard times. Industrial and Commercial Training, 44(5), 259 - 267.

62. Matos, P., Simoes, M., \& Esposito, M. (2014). Improving change management: how communication nature influences resistance to change. Journal of Management Development, 33(4), 324 - 341.

63. McCabe, D. (2010). Taking the long view: A cultural analysis of memory as resisting and facilitating organizational change. Journal of Organizational Change Management, 23(3), 230 - 250.

64. Mertkan, S., Gilanlioglu, I., \& McGrath, S. (2016). Internationalizing higher education: from grand plans to evolving responses. Journal of Organizational Change Management, 29(6), 889 - 902.

65. Millar, C., Hind, P., \& Magala, S. (2012). Sustainability and the need for change: organisational change and transformational vision. Journal of Organizational Change Management, 25(4), 489 - 500.

66. Miller, G. J., \& Whicker, M. L. (1999). Handbook of Research Methods in Public Administration. New York: Marcel Dekker, Inc. 
67. Mingze, L., Liu, W., Han, Y., \& Zhang, P. (2016). Linking empowering leadership and change-oriented organizational citizenship behavior: The role of thriving at work and autonomy orientation. Journal of Organizational Change Management, 29(5), 732 - 750.

68. Muhammad, S. A. (2016). Impact of change readiness on commitment to technological change, focal, and discretionary behaviors: Evidence from the manufacturing sector of Karachi. Journal of Organizational Change Managemen, 29(2), 222241.

69. Noora, J. (2013). Organizational change as practice: a critical analysis. Journal of Organizational Change Management, 26(6), $1003-1019$.

70. Nothnagel, K. (n.d.).

71. Nyström, M. E., Höög, E., Garvare, R., Weinehall, L., \& Ivarsson, A. (2013). Change and learning strategies in large scale change programs: Describing the variation of strategies used in a health promotion program. Journal of Organizational Change Management, 26(6), 1020 - 1044.

72. Pardo-del-Val, M., \& Sal, C. M.-F. (2012). Participative management and its influence on organizational change. Management Decision, 50(20), 1843-1860.

73. Parker, D., Charlton, J., Ribiero, A., \& Raghuvar, D. P. (2013). Integration of project-based management and change management : Intervention methodology. International Journal of Productivity and Performance Management, 62(5), 534544.

74. Pitsakis, K., Biniari, M. G., \& Ku, T. (2012). Resisting change: organizational decoupling through an identity construction perspective. Journal of Organizational Change Management, 25(6), 835 - 852.

75. Reissner, S. C. (2010). Change, meaning and identity at the workplace. Journal of Organizational Change Management, 23(3), $287-299$.

76. Rill, B. (2016). Resonant co-creation as an approach to strategic innovation. Journal of Organizational Change Management, 29(7), 1135-1152.

77. Rodwell, J., Flower, R., \& Demir, D. (2015). Occupational power differentiates employee impacts under continuing change. Journal of Organizational Change Management, 28(4), 656 - 668.

78. Rusly, F. H., James, C. L., \& Sun, P. (2012). Positioning change readiness in knowledge management research. Journal of Knowledge Management, 16(2), 329 - 355.

79. Sementelli, A. J. (2016). Organisation Development, Change Management, and The a Priori: Introducing Parrhesia. Journal of Organizational Change Management, 29(7), 1083 - 1096.

80. Sghari, A. (2016). Can the staff recognition ensure planned process of organizational change? Journal of Organizational Change Management, 29(5), 782 - 792.

81. Sikdar, A., \& Payyazhi, J. (2014). A process model of managing organizational change during business process redesign. Business Process Management Journal, 20(6), 971-998.

82. Simpson, P. (2012). Complexity and change management: analyzing church leaders' narratives. Journal of Organizational Change Management, 25(2), 283 - 296.

83. Sjoerd, H. v.-d., Schalk, R., \& Fre, C. (2016). What's in it for me? A managerial perspective on the influence of the psychological contract on attitude towards change. Journal of Organizational Change Management, 29(2), 263 - 292. 
84. Sorensen, C., \& Sarjeant-Jenkins, R. (2016). "Sustainable growth with sustainable resources: Using change management, participative consultation, and grassroots planning for a new future. Library Management, $37(3), 114$ - 124.

85. Soriano, D. R. (2012). Change management in the entrepreneurial Latin-American organizations: an overview. Journal of Organizational Change Management, 25(5), 653 - 656.

86. Sridarran, P., \& Fernando, N. G. (2016). Change management framework to enable sustainable outsourcing of facilities management services. Built Environment Project and Asset Management, 6(3), 317 - 331.

87. Sushil, N. S. (2010). Managing continuity and change: a new approach for strategizing in e-government. Transforming Government: People, Process and Policy, 4(4), 338 - 364.

88. Tromp, D. K. (2006). Proposal and Thesis Writing: An Introduction. Nairobi : Pauline Publications Africa.

89. Tummers, L., Kruyen, P. M., Vijverberg, D. M., \& Voesenek, T. J. (2015). Connecting HRM and change management: the importance of proactivity and vitality. Journal of Organizational Change Management, 28(4), 627 - 640.

90. Vora, M. K. (2013). Business excellence through sustainable change management. The TQM Journal, $25(6), 625$ - 640.

91. Wilhoit, E. D., Gettings, P., Malik, P., Hearit, L. B., Buzzanell, P. M., \& Ludwig, B. (2016). STEM faculty response to proposed workspace changes. Journal of Organizational Change Management, 29(5), 804 - 815.

92. Wu, Y., Wei, Z., \& Liang, Q. (2011). Top management team diversity and strategic change: The moderating effects of pay imparity and organization slack. Journal of Organizational Change Management, 24(3), 267 - 281.

93. Xerri, M. J., Nelson, S. A., \& Brune, Y. (2015). NPM and change management in asset management organisations. Journal of Organizational Change Management, 28(4), 641-655.

94. Xiaojun, X. (2016). Co-evolution between institutional environments and organizational change: The mediating effects of managers' uncertainty. Journal of Organizational Change Management, 29(3), 381-403.

95. Yazici, S., Köseoglu, M. A., \& Okumus, F. (2016). Identification of growth factors for small firms: evidence from hotel companies on an island. Journal of Organizational Change Management, 29(6), 994 - 1029.

96. Yeo, R. K., \& Marquardt, M. J. (2015). Think before you act: organizing structures of action in technology-induced change. Journal of Organizational Change Management, 28(4), 511 - 528.

97. Zuber-Skerritt, O., \& Louw, I. (2014). Academic leadership development programs: a model for sustained institutional change. Journal of Organizational Change Management, 27(6), 1008 - 1024. 